\title{
Antibiotics versus biofilm: an emerging battleground in microbial communities
}

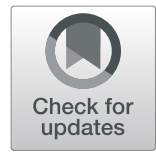

\author{
Divakar Sharma, Lama Misba and Asad U. Khan ${ }^{*}$ (D)
}

\begin{abstract}
Biofilm is a complex structure of microbiome having different bacterial colonies or single type of cells in a group; adhere to the surface. These cells are embedded in extracellular polymeric substances, a matrix which is generally composed of eDNA, proteins and polysaccharides, showed high resistance to antibiotics. It is one of the major causes of infection persistence especially in nosocomial settings through indwelling devices. Quorum sensing plays an important role in regulating the biofilm formation. There are many approaches being used to control infections by suppressing its formation but CRISPR-CAS (gene editing technique) and photo dynamic therapy (PDT) are proposed to be used as therapeutic approaches to subside bacterial biofim infections, especially caused by deadly drug resistant bad bugs.
\end{abstract}

Keywords: Biofilm, Antibiotics resistance, Drug resistance bacterial infection

\section{Introduction}

Bacterial biofilms are serious global health concern due to their abilities to tolerate antibiotics, host defence systems and other external stresses; therefore it contributes to persistent chronic infections [27, 33]. Biofilms are immobile microbial communities which colonize and grow on surfaces of medical implants such as sutures, catheters and dental implants, by self-produced extracellular polymeric substances and cause infections which can only be treated by their removal and leads to the unaffordable treatment as well as mental-illness to patients $[26,52]$. Biofilm comprises of the crammed bacterial population by extra-cellular matrix (ECM) which possesses bacterial secreted polymers such as exopolysaccharides (EPS), extracellular DNA (e-DNA), proteins and amyloidogenic proteins [140, 146]. Formation of biofilm is well-regulated multi step events such as (i) adsorption of molecules (macro and micro molecules) to surfaces; (ii) bacterial adhesion to the surface and release of extracellular polymeric substances (EPS); (iii) colony formation and biofilm maturation. Metabolic activity of the bacterial biofilm communities have altered as compared to the planktonic one such as increased rates of EPS production, activation or inhibition of particular

\footnotetext{
* Correspondence: asad.k@rediffmail.com

Medical Microbiology and Molecular Biology Laboratory, Interdisciplinary

Biotechnology Unit, Aligarh Muslim University, Aligarh 202002, India
}

genes associated with biofilm formation and decreased growth rate [39].

Biofilms provides the protection to the microorganism not only from altered $\mathrm{pH}$, osmolarity, nutrients scarcity, mechanical and shear forces [28, 41, 82] but also block the access of bacterial biofilm communities from antibiotics and host's immune cells $[27,126]$. Therefore, biofilm matrix gives the additional resistance power to bacteria which makes them to not only tolerate harsh conditions but also resistant to antibiotics which lead to the emergence of bad bugs infections like multi drug resistant, extensively drug resistant and totally drug resistant bacteria.

Formation of biofilms in mycobacteria can be defined as similar as other biofilms communities. However, some mycobacteria can develop biofilms on surfaces as well as the air-media interface [100]. Due to deficiency of surface fimbriae or pili in mycobacteria, few proteins have been reported as potential factors for the aggregation and attachment of mycobacteria cells [83]. Mycobacteria do not produce the usual exopolysaccharide but it has ability to attach a varieties of surfaces [150] and form fully developed biofilms [101, 149].

Panels of studies have reported the role of various molecules in the biofilm formation and maintenance of its composition. Glycopeptidolipids are indispensable for initial surface attachment during biofilm formation in 
Mycobacterium smegmatis [111]. It has been suggested earlier that shorter chain mycolic acids may form a hydrophobic extracellular matrix [102]. Shorter-chain mycolic acids have essential in the development of biofilm structure of the non-motile mycobacteria [100]. Mycolic acids, a potential permeability barrier could be associated to the higher resistance to antibiotics [149]. These molecules also have an essential role in sliding motility that can be correlated with biofilm spreading $[81,111,112]$. Role of GroEL1 chaperone in the biofilms development of $M$. smegmatis has already been reported $[35,101,102]$.

Growth pattern of Mycobacterium species are different such as M. chelonae and M. fortuitum form biofilm as vertical and entire surface growth, respectively [93]. Cording has been associated with pathogenicity of various mycobacterial species $[46,81,93,145]$ and its link in the biofilm development by $M$. tuberculosis are underway [22].

Mycobacterial species form biofilms in the various environmental reservoirs $[37,38,115,116]$ and these reservoirs participate in the outbreaks of mycobacterial infections [59, 133, 135, 136]. In one of the studies, $M$. chimaera (nosocomial pathogen) biofilm has shown to be associated with their contamination of heater-cooler units of surgery [62].

Discovery of biofilms in M. tuberculosis suggested that the infection associated with clinical biomaterial and prosthetic joints in particular $[16,45,123]$ and removal of these biomaterials was indispensable to manage these infections otherwise it could leads to the development of antibiotic resistance phenomenon. It was reported in previous study that $M$. tuberculosis can also develop a biofilm in vitro [100]. It was suggested that mycolic acids as well as DNA, were crucial in the development and regulation of $M$. tuberculosis biofilms [94, 101].

Few studies suggest that casseous necrosis and cavitation in lung tissue of $M$. tuberculosis is potentially due to the biofilms formation [13,67] which might decrease in the activity of anti-mycobacterial drugs against $M$. $t u$ berculosis biofilms $[55,100]$. These discoveries open the new research areas which not only explore the mechanism of biofilms formation but also the antibiotics resistance and these potential targets could help in the development of alternative therapies against drug resistance tuberculosis.

\section{Ultrastructure of biofilm}

Microbial biofilm is the grouping of sessile microbial communities which is attached with substratum and embedded in the self produced pool of non-crystalline extracellular polymeric matrix [52]. Bacterial biofilm communities differ from the planktonic ones in different ways such as growth rate, gene expression, transcription and translation because these biofilms communities live in different microenvironments which have higher osmolarity, nutrient scarcity and higher cell density of heterogeneous bacterial communities. Formation of the three-dimensional structure of biofilm is the dynamic process by heterogeneous bacterial communities. Bacteria living within the biofilms are protected from the varieties of environmental stresses, such as desiccation, antimicrobials attack by the immune system and ingestion by protozoa hence this architecture makes the biofilm communities to advance as compared to planktonic one [143]. Coordination within the biofilm via cell-to-cell communication called quorum sensing (QS) in which accumulation of signaling molecules in extracellular environment leads to regulation of the specific genes expression. Some bacterial species use QS to coordinate the disassembly of the biofilm community [121].

Development of biofilms is multi step process. It starts with the initial adherence of bacteria to the substratum and irreversible attachment followed by their colonization in which modification in genes/proteins expression occurs followed by exponential growth phase. The exopolysaccharides (EPS) and water channels formation occur, facilitating nutrient supply which leads to the maturation of the biofilms. Ultimately surface detachment of the cells starts in the environments which again restart/recycle the biofilm formation onto the new surfaces.

\section{Infections associated with biofilms}

Approximately $80 \%$ of chronic and recurrent microbial infections in the human body are due to bacterial biofilm. Microbial cells within biofilms have shown 10-1000 times more antibiotics resistance than the planktonic cells [79]. Biofilm is formed in diverse environmental niches, including freshwater rivers, rocks, deep-sea vents and hydrothermal hot springs. Biofilm-related infections can be broadly divided into two types. The biofilms may be formed on the abiotic surfaces, especially infections associated with indwelling medical devices [34] and native biofilm infections of host tissue [21]. Urinary tract and bloodstream infections can be caused by the biofilm initially formed on medical implants, such as heart valves, catheters, contact lenses, joint prostheses, intrauterine devices and dental unit. These infections can only be treated by removal of the implants which not only increasing the cost of the treatment but also it becomes problematic for patients [26]. Host tissue related biofilm infections are often chronic, including chronic lung infections of cystic fibrosis patients, chronic osteomyelitis, chronic prostatitis, chronic rhinosinusitis, chronic otitis media, chronic wounds, recurrent urinary tract infection, endocarditis, periodontitis and dental caries [21]. Some of the major biofilm associated infections causing human diseases are listed in Table 1. 
Table 1 Bacterial species involved in biofilm associated infection and their adherent surfaces

\begin{tabular}{|c|c|c|c|c|}
\hline S. No. & Bacterial Species & Infection/Diseases & Surface & References \\
\hline 1 & Streptococcus mutans & $\begin{array}{l}\text { Dental caries } \\
\text { Endocarditis }\end{array}$ & $\begin{array}{l}\text { Tooth surface } \\
\text { Vascular grafts }\end{array}$ & {$[1,84]$} \\
\hline 2 & Enterococcus faecalis & $\begin{array}{l}\text { Endocarditis } \\
\text { Root canal infection }\end{array}$ & $\begin{array}{l}\text { Heart valves } \\
\text { Urinary catheters } \\
\text { Tooth } \\
\text { Central venous catheters }\end{array}$ & [85] \\
\hline 3 & Klebsiella pneumonia & $\begin{array}{l}\text { Pneumonia } \\
\text { Respiratory tract infection } \\
\text { Urinary tract infection } \\
\text { Pyogenic liver abscess }\end{array}$ & $\begin{array}{l}\text { Lungs } \\
\text { Liver }\end{array}$ & [24] \\
\hline 4 & Pseudomonas aeruginosa & $\begin{array}{l}\text { Nosocomial infection } \\
\text { Otitis media } \\
\text { Cystic fibrosis }\end{array}$ & $\begin{array}{l}\text { Central venous Catheters } \\
\text { Middle ear } \\
\text { Prostheses } \\
\text { Lungs } \\
\text { Contact lenses }\end{array}$ & {$[53,139,142]$} \\
\hline 5 & $\begin{array}{l}\text { Staphylococcus sp (Staphylococcus aureus; } \\
\text { Staphylococcus epidermidis). }\end{array}$ & $\begin{array}{l}\text { Nosocomial infections } \\
\text { Chronic wounds } \\
\text { Endocarditis } \\
\text { Mucoloskeletal } \\
\text { Infections } \\
\text { Otitis media }\end{array}$ & $\begin{array}{l}\text { Sutures } \\
\text { Central venous catheters } \\
\text { Arteriovenous shunts } \\
\text { Prostheses } \\
\text { Surfaces/deep skin } \\
\text { Prostheses, Heart valves } \\
\text { Bones, Middle ear }\end{array}$ & {$[6,109]$} \\
\hline 7 & Escherichia coli & $\begin{array}{l}\text { Bacterial prostatitis } \\
\text { Urinary tract infection } \\
\text { Otitis media }\end{array}$ & $\begin{array}{l}\text { Prostheses, Urinary tract } \\
\text { Urinary catheters } \\
\text { Middle ear }\end{array}$ & [56] \\
\hline 8 & Haemophilus influenza & Otitis media & Middle ear & {$[113,130]$} \\
\hline 9 & Burkholderia cepacia & Cystic fibrosis & Lungs & [152] \\
\hline 10 & Mycobacterium tuberculosis & Tuberculosis & Lungs & [110] \\
\hline
\end{tabular}

\section{Resistance to antibiotics in biofilms communities}

Antibiotic resistance of bacteria in the biofilm communities contributes to the chronic infections. Resistance mechanisms of biofilm communities are not similar as the planktonic ones such as target site mutations, lower cell permeability, efflux pumps, drug modifying enzymes and drug neutralizing proteins $[14,70,72,76,77,96,117,118$, 137, 138]. A panel of studies suggested that conventional antibiotic resistance mechanisms are unable to explain the various cases of antibiotic-resistant biofilm infections [2, $5,19,144]$. On the basis of these studies we can't ignore the possibility of the conventional resistance mechanisms in biofilms which contribute to the antibiotic resistance. It has been reported earlier that repeated exposure of ceftazidime in biofilm-growing Pseudomonas aeruginosa developed the conventional type of intrinsic antibiotic resistance in biofilms infections [10]. In biofilm communities, antibiotics resistance appears due to various strategies (Fig. 1) such as slow or incomplete penetration of the antibiotics into the biofilm $[42,71,78,95,119,124,125]$, an altered chemical microenvironment within the biofilm $[32,108,129,132,147,151]$ and a subpopulation of micro-organisms in a biofilm a type of cell differentiation like to spore formation $\}[25,29,43]$. These mechanisms are the consequences of the multicellular nature of biofilms which leads to the antibiotics resistance of biofilm communities [30] along with the known conventional resistance mechanisms and makes the failure of treatment strategy. Multicellular nature of biofilm is the key factor of antibiotics resistance of biofilm communities which is the actual cause of the resistance mechanisms as discussed above. A series of researches exists on formation of biofilm as a multicellular developmental process [65, 98, 127]. Extracellular polymeric substances (EPS) hold the bacterial cells together and lead to the development of multicellular consortia which makes the heterogenous environment inside the biofilm and initiates the biofilm to function as a multicellular system. Biofilm development is well organized and during its development intercellular and intracellular signaling occurs. A panel of genes/proteins are upregulated as well as downregulated for attachments of bacteria onto substratum surface and pathways differentiation $[15,27,98,99,141]$. Maturation of the biofilm into complex structures is regulated by the signalling among the cells by the quorum sensing process [31]. Multicellularity nature of biofilm bacterial communities is responsible for antibiotics resistance; if we can disrupt any step in the formation of multicellular structure of the biofilm than antibiotics efficacy as well as the host defences might be increased which leads to quick treatment of this persistent infection. On the basis of these observations we can say that multicellular developmental process of the 


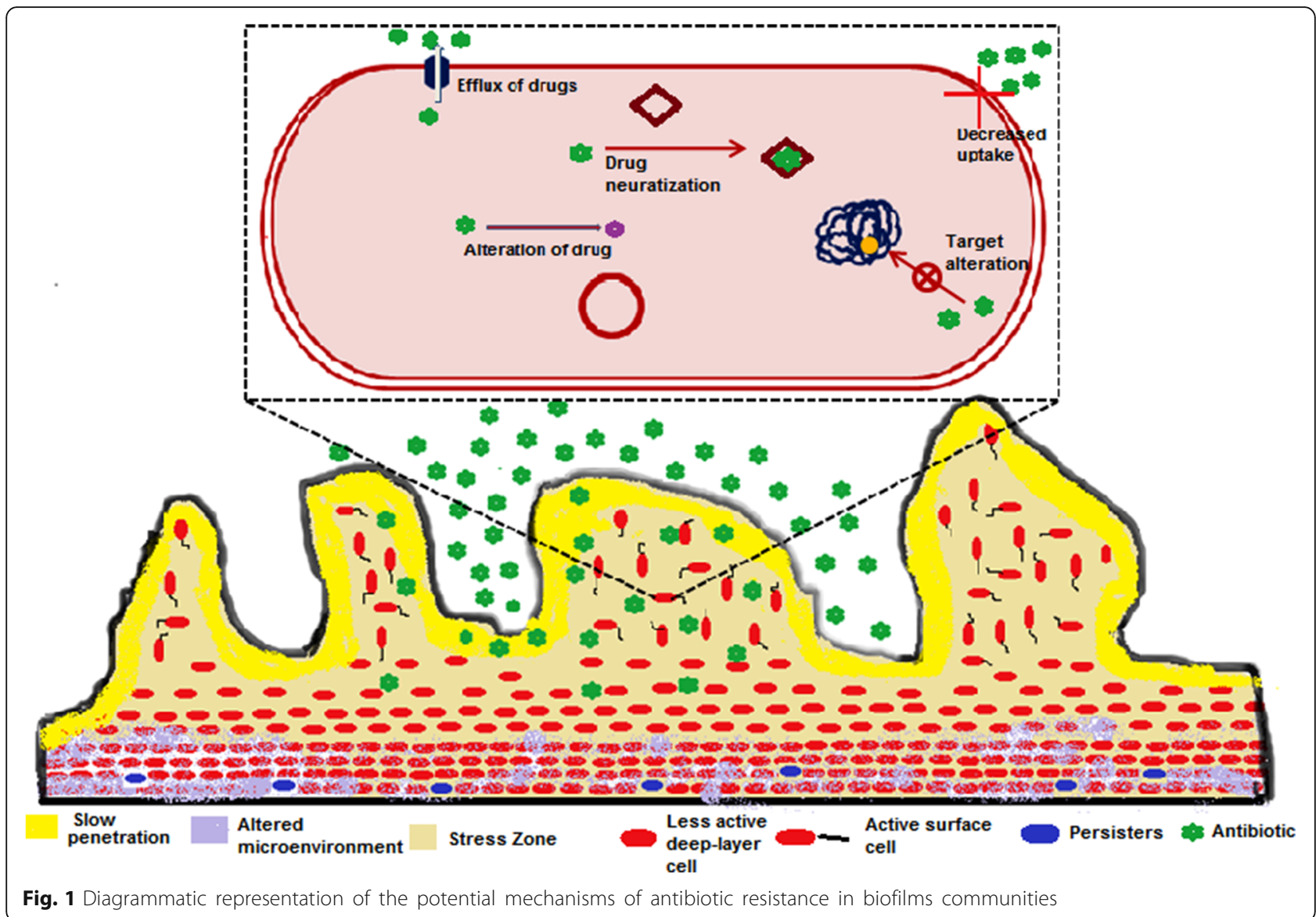

biofilms are important because its insight will open up new targets and approaches for designing new drug molecules against antibiotics resistant microorganisms.

Antibiotics resistant state of the biofilm cells lead to a treatment complications in the series of human infections which include biofilm formation on various biological implants such as, heart catheters, urinary catheters, joint implants and replacement of heart valves [120]. Biofilms pose a threat to the human race because of their persistent nature and plays a major role in certain pathogenic infections $[40,58,104,120]$. Studies suggested that role of EPS have been conferring tolerance to aminoglycosides [41, 61]. EPS might quench the activity of antibiotics that diffuse through the biofilms via diffusion-reaction inhibition phenomenon, which may chelates the antibiotics by complex formation or degrade through enzymatically based reactions $[17,105]$. Stationary phase (a slow or non-growth phase of the bacterial life cycle) and viable-but-nonculturable state (VBNC state or a state of dormancy) are the ways of survival for bacterial biofilms communities under antibiotics stress [20,73]. Biofilms possesses many cells of stationary phase which have the decreased antibiotics susceptibility to the antibiotics. Among them at least $1 \%$ becomes tolerant to antibiotics $[4,80]$. Many biofilms communities enter into the stationary phase with time which suggested that older biofilms show higher tolerance to antibiotics [89]. Persisters are another dormancy state of bacterial subpopulation, which have the multidrug tolerance phenotypic rather than genetic variations $[8,47]$. In stationary state of biofilms communities, persisters might be the prevalent [60].

One of the antibiotics resistance mechanisms of biofilms communities is the uptake of resistance genes by horizontal gene transfer [79]. Biofilms provides the compatible conditions for the horizontal gene transfer such as high cell density, increased genetic competence and accumulation of genetic elements or uptake of resistance genes [41]. Conjugation is the only mechanism of horizontal transfer of resistant genes in biofilms and may confirm the resistance to several antibiotics. Few studies suggested that conjugation has been shown more efficient in biofilms as compared to planktonic ones $[66,75,114,134]$.

A penal of studies reported that in vitro mycobacterial biofilms were resistant to antibiotics (amikacin and clarithromycin) or disinfectants $[44,103]$. It has been reported earlier that differences between the MIC and minimum biofilm eradication concentration (MBEC) in 
4 species of RGM [91] and suggested that ciprofloxacin as an effective antibiotic against these biofilms as compared to clarithromycin and amikacin.

Few studies shown the effect of antibiotics in different stages of biofilm development [90-92] and revealed that at early stage of biofilm development antibiotics treatment was more effective, probably due to the cells which are not completely adapted into biofilm communities. In an attempt to evaluate mechanisms for these resistance patterns, it has been suggested that permeability of anti-tuberculosis drugs were independent among the mycobacterial species [103]. Metabolic state and activation of resistance genes (like methylases) are indispensable for the development of antibiotics resistance in mycobacteria [36, 44].

\section{Alternative approaches to control the biofilm related infections}

Successful treatment of biofilm-associated infections is troubled due to high antibiotic resistance in these bacterial communities. Classical antibiotics chemotherapy is unable to completely eradicate bacterial cells which are situated in the central region of the biofilm and leads to the emergence of the worsen situation globally. Therefore to overcome the drug resistance of bacterial biofilm communities; alternative strategies (Fig. 2) and novel antibiofilm agents have been studied earlier $[9,48-50,54,63,64,69,74,86-88,92,128$, $131,148,153,154]$.

Naturally produced small molecules by bacterial biofilm communities such as D-amino acids and Polyamine norspermidine; induced the dispersal of mature biofilms which could prevent biofilm formation in $S$. aureus and $E$. coli $[50,63,64]$. These molecules could be used as antibiofilm agent in the biofilm dispersal strategy. Muñoz-Egea et al. [92] reported that antibiofilm molecules ( $\mathrm{N}$-acetylcysteine/NAC and Tween 80) alone and in combination with antibiotics were effective against non-pigmented RGM biofilms [92]. Tween 80 is more active against mycobacterial biofilm than NAC because mycobacterial cell wall as well as extracellular matrix possesses high lipid content and suggested that synergistic effect of drugs and anti-biofilm agent may effective in the treatment of infections associated with mycobacterial biofilms communities.

Degradation of the biofilm matrix by biofilm matrix degrading enzymes (DNase I, Dispersin B (DspB) and a-amylase) is also another promising antibiofilm strategy. Degradation of biofilm structural component allows the increased penetration of antibiotics which enhances the antibiotics effeciency. DNase I, DspB and $\alpha$-amylase degrade eDNA, biofilm matrix and exopolysaccharides,

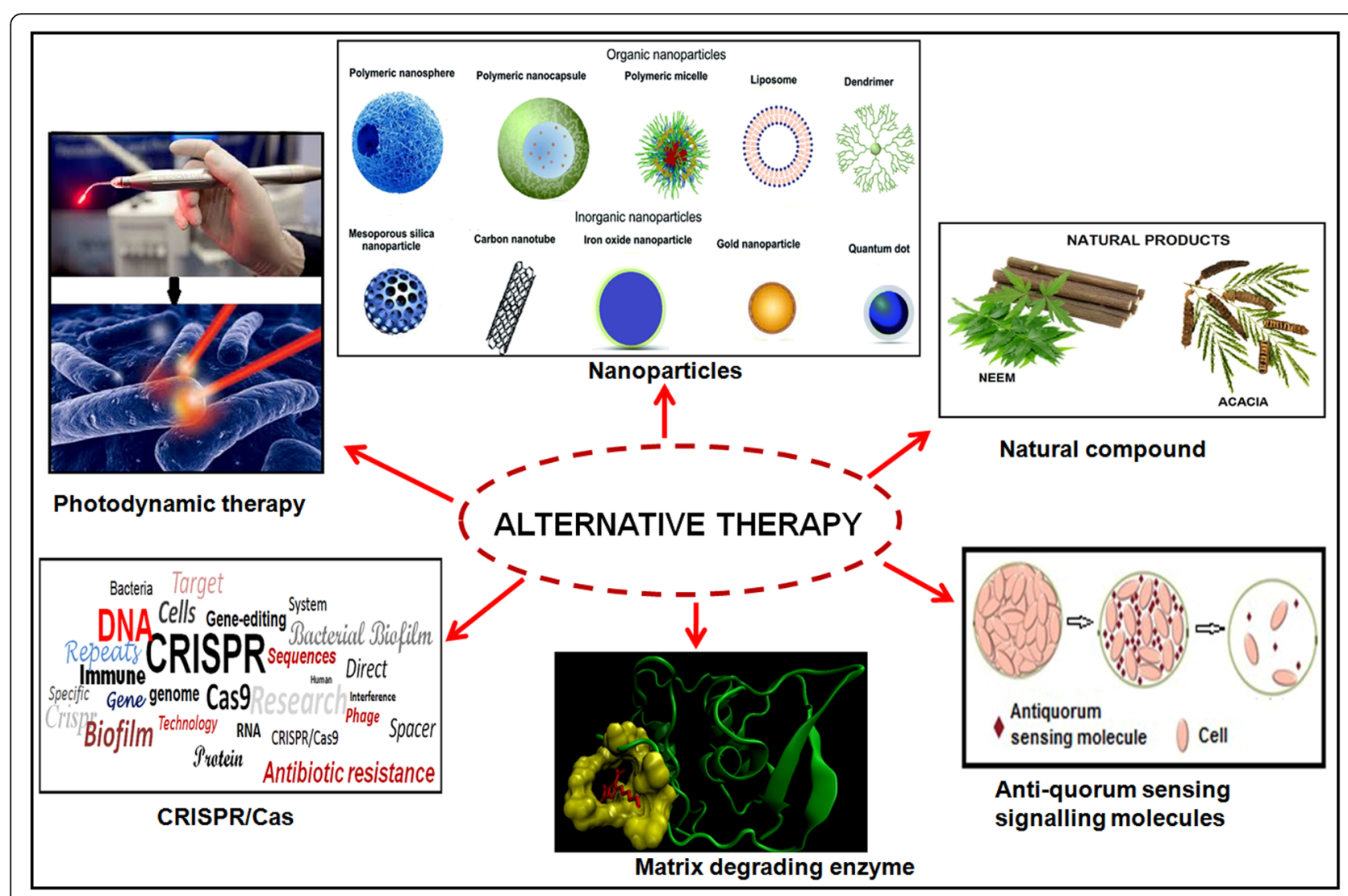

Fig. 2 Diagrammatic representation of the alternative approaches against antibiotic resistant biofilms communities 
respectively [128, 131], which not only inhibit biofim formation but also degrading the mature biofilms in various microbes such as $S$. aureus, Vibrio cholerae and $P$. aeruginosa [57].

Formation of biofilms were controlled by the quorum sensing (QS) signalling genes and their products. Various inhibitors/compounds are able to disturb the QS signalling cascade and used as alternative therapy for the treatment of biofilm-related infections. Halogenated furanone isolated from Delisea pulchra (marine algae) interrupt the bacterial QS signalling [74]. Recently, Kaur et al. [58] reported an acyclic diamine (ADM 3), showed better antimicrobial activity and antibiofilm activity [58]. Attenuation of bacterial QS signalling by ginseng extract, garlic extract, usnic acid and azithromycin possesses inhibitory activity against bacterial and fungal biofilms [18, 51, 122]. Signalling molecule nitric oxide (NO) disperse the biofilms in $P$. aeruginosa and enhances the activity of antimicrobial compounds via stimulation of c-di-GMP-degrading phosphodiesterases, which induce a switch to planktonic growth [12]. Most recently our group used the CRISPRi technology to knockdown the luxS gene of QS signalling and fimbriae associated gene (fimH) for controlling the biofilm mediated infections [153, 154].

Bacterial and actinomycetes have been shown to produce bioactive agents/natural compounds with antibiofilm properties. Methanolic extract of a coral-associated actinomycete helps to reduce biofilm formation of $S$. aureus [11]. Another natural product, 4-phenylbutanoic acid show high antibiofilm activity against Gram positive and Gram negative bacteria [97]. Azadiracta indica (Neem) and Acacia extracts showed antimicrobial effect against S.mutans and S. faecalis [3, 7].

Nanoparticles have considered as the alternative of the antibiotics to combat multidrug resistance and biofilm based infections (Pelgrift \& Friedman [106]). Limitations of the conventional antibiotic treatments (reduced penetration and retention in cell or biofilm) were overcome by their nano-formulations which have the ability to cross the biological barrier. Since the last few years, different type of nanoparticles have been used as antimicrobial and antibiofilm metal nanoparticles, organic nanoparticles, green nanoparticles and their combinations [9]. A panel of reports exists on nanoparticles based elimination of bacterial biofilm communities (Hernández-Sierra et al. [48, 49, 54, 69]). Kulshrestha et al. [68] reported that suppressive effect of $\mathrm{CaF} 2-\mathrm{NPs}$ on genes associated with major virulence factors (vicR, $g t f C$, $f t$, spaP, comDE) of $S$. mutans and suggested the suppression of enzymatic activity associated with glucan synthesis, cell adhesion, acid production, acid tolerance and quorum sensing which leads to biofilm inhibition [68]. In the last few years' photodynamic therapy (PDT) was used to treat various type of infection like as bacterial, fungal, viral, protozoa or even parasitic infection. It has reported earlier that PDT has sufficiently reduced the clinically-relevant microbes, such as drug resistant Gram-positive and Gram-negative bacteria [23]. PDT has significant advantages over conventional treatment owing to its ability of selective binding to the membranes of pathogenic cells and the possibility for accurate delivery of light to the affected tissue for the maximal damage of microbes as well as minimal damage of the host [107]. Recently, our group has shown that PDT could be used to eliminate the biofilms related issues in S.mutans infection (Lama et al., 2016; 2017; 2018).

\section{Conclusion and future prospects}

Bacterial antibiotic resistance is also one of the consequences of the bacterial biofilm communities which contribute to the chronic infections. These biofilm communities have few additional resistance mechanisms as compared to the planktonic ones which hamper the treatments option and leads to emergence as well as spreading of the chronic bad bugs. Emergence and spreading of multidrug resistant, extremely drug resistant and total drug resistant strains of $M$. tuberculosis have worsened the current situation across the globe. In this timeline review we have discussed the mechanisms of antibiotics resistance in biofilms communities and alternative therapeutic options to combat the resistance mediated by chronic bacterial biofilm infections. Alternative approaches, like nanoparticles based antibiotics formulation, novel anti-biofilm agents, CRISPRi gene editing technologies and photodynamic therapy might be the future options to treat the infections caused by multidrug resistant, extremely drug resistant and total drug resistant strains of M.tuberculosis which might be one of the ways to achieve the goal of TB free world declared by WHO.

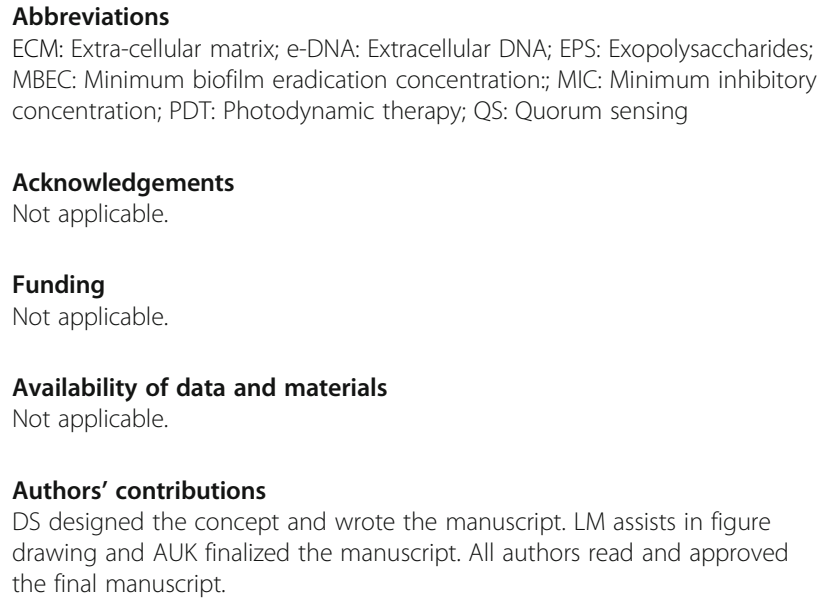

ECM: Extra-cellular matrix; e-DNA: Extracellular DNA; EPS: Exopolysaccharides; MBEC: Minimum biofilm eradication concentration:; MIC: Minimum inhibitory concentration; PDT: Photodynamic therapy; QS: Quorum sensing

\section{Acknowledgements}

Not applicable.

Funding

Not applicable.

Availability of data and materials

Not applicable.

Authors' contributions

DS designed the concept and wrote the manuscript. LM assists in figure drawing and AUK finalized the manuscript. All authors read and approved the final manuscript.

Ethics approval and consent to participate Not applicable. 


\section{Consent for publication}

Not applicable.

\section{Competing interests}

The authors declare that they have no competing interests.

\section{Publisher's Note}

Springer Nature remains neutral with regard to jurisdictional claims in published maps and institutional affiliations.

\section{Received: 27 February 2019 Accepted: 30 April 2019} Published online: 16 May 2019

\section{References}

1. Abranches J, Miller JH, Martinez AR, Simpson-Haidaris PJ, Burne RA, Lemos $\mathrm{JA}$. The collagen-binding protein $\mathrm{Cnm}$ is required for Streptococcus mutans adherence to and intracellular invasion of human coronary artery endothelial cells. Infect Immun. 2011;79:2277-84

2. Alekshun MN, Levy SB. The mar regulon: multiple resistances to antibiotics and other toxic chemicals. Trends Microbiol. 1999:7:410-3.

3. Almas $\mathrm{K}, \mathrm{Al}$-Bagieh $\mathrm{NH}$. The antimicrobial effects of bark and pulp extracts of miswak, Salvadora persica. Biomed letters. 1999:60:71-5.

4. Amato SM, et al. The role of metabolism in bacterial persistence. Front Microbiol. 2014:5:70

5. Anderl JN, Franklin MJ, Stewart PS. Role of antibiotic penetration limitation in Klebsiella pneumoniae biofilm resistance to ampicillin and ciprofloxacin. Antimicrob Agents Chemother. 2000;44:1818-24.

6. Arciola CR, Campoccia D, Speziale P, Montanaro L, Costerton JW. Biofilm formation in Staphylococcus implant infections. A review of molecular mechanisms and implications for biofilm-resistant materials. Biomaterials. 2012:33:5967-82

7. Arias ME, Gorney JD, Cadmani NM, Vattuone MA, Isla MI. Antibacterial activity of ethonolic and aqueous extracts of Acacia aroma. Ex Hook et. Arn. Life Sci. 2004;75:191-202.

8. Ayrapetyan M, Williams TC, Oliver JD. Bridging the gap between viable but non-culturable and antibiotic persistent bacteria. Trends Microbiol. 2015;23: 7-13.

9. Baek YW, An YJ. Microbial toxicity of metal oxide nanoparticles (CuO, NiO, $\mathrm{ZnO}$, and Sb2O3) to Escherichia coli, Bacillus subtilis, and Streptococcus aureus. Sci Total Environ. 2011;409(8):1603-8.

10. Bagge N, Ciofu O, Skovgaard LT, Høiby N. Rapid development in vitro and in vivo of resistance to ceftazidime in biofilm-growing Pseudomonas aeruginosa due to chromosomal beta-lactamase. APMIS. 2000;108:589-600.

11. Bakkiyaraj D. Pandian SK. In vitro and in vivo antibiofilm activity of a coral associated actinomycete against drug resistant Staphylococcus aureus biofilms. Biofouling. 2010;26:711-7.

12. Barraud N, Schleheck D, Klebensberger J, Webb JS, Hassett DJ, Rice SA, Kjelleberg S. Nitric oxide signaling in Pseudomonas aeruginosa biofilms mediates phosphodiesterase activity, decreased cyclic di-GMP levels, and enhanced dispersal. J Bacteriol. 2009;191:7333-42.

13. Basaraba RJ, Ojha AK. Mycobacterial biofilms: revisiting tuberculosis bacilli in extracellular necrotizing lesions. Microbiol Spectr. 2017;5(3)

14. Beauclerk AAD, Cundliffe E. Site of action of two ribosomal RNA methylases responsible for resistance to aminoglycoside. J Mol Biol. 1987;193:661-71.

15. Beloin C, Ghigo JM. Finding gene-expression patterns in bacterial biofilms. Trends Microbiol. 2005;13:16-9.

16. Berbari EF, Hanssen AD, Duffy MC, Steckelberg JM, Osmon DR. Prosthetic joint infection due to Mycobacterium tuberculosis: a case series and review of the literature. Am J Orthop. 1998:27:219-27.

17. Billings N, Birjiniuk A, Samad TS, Doyle PS, Ribbeck K. Material properties of biofilms- a review of methods for understanding permeability and mechanics. Rep Prog Phys. 2015;78:036601.

18. Bjarnsholt $T$, Jensen $P O$, Rasmussen $T B$, Christophersen L, Calum H, Hentzer M, Hougen HP, Rygaard J, Moser C, Eberl L, Høiby N. Garlic blocks quorum sensing and promotes rapid clearing of pulmonary Pseudomonas aeruginosa infections. Microbiology. 2005;15:3873-80.

19. Brooun A, Liu S, Lewis K. A dose-response study of antibiotic resistance in Pseudomonas aeruginosa biofilms. Antimicrob Agents Chemother. 2000;44: 640-6.

20. Brown MR, Allison DG, Gilbert P. Resistance of bacterial biofilms: a growthrelated effect? J Antimicrob Chemother. 1988;22:777-83.
21. Burmolle M, Thomsen TR, Fazli M, Dige I, Christensen L, Homøe P, Tvede M, Nyvad B, Tolker-Nielsen T, Givskov M, Moser C. Biofilms in chronic infections a matter of opportunity - monospecies biofilms in multispecies infections. FEMS Immunol Med Microbiol. 2010;59:324-36.

22. Caceres N, Vilaplana C, Prats C, Marzo E, Llopis I, Valls J, et al. Evolution and role of corded cell aggregation in Mycobacterium tuberculosis cultures. Tuberculosis. 2013;93:690-8.

23. Carpenter BL, Situ X, Scholle F, Bartelmess J, Weare WW, Ghiladi RA. Antiviral, antifungal and antibacterial activities of a BODIPY-based photosensitizer. Molecules. 2015;20:10604-21.

24. Chung PY. The emerging problems of Klebsiella pneumoniae infections: carbapenem resistance and biofilm formation. FEMS Microbiol Lett. 2016; 363:219.

25. Cochran WL, McFeters GA, Stewart PS. Reduced susceptibility of thin Pseudomonas aeruginosa biofilms to hydrogen peroxide and monochloramine. J Appl Microbiol. 2000;88:22-30.

26. Costerton JW, Montanaro L, Arciola CR. Biofilm in implant infections: its production and regulation. Int J Artif Org. 2005;28:1062-8.

27. Costerton JW, Stewart PS, Greenberg EP. Bacterial biofilms: a common cause of persistent infections. Science. 1999;284:1318-22.

28. Costerton JW, Lewandowski Z. Microbial biofilms. Annu Rev Microbiol. 1995; 49:711-45.

29. Das JR, Bhakoo M, Jones MV, Gilbert P. Changes in the biocide susceptibility of Staphylococcus epidermidis and Escherichia coli cells associated with rapid attachment to plastic surfaces. J Appl Microbiol. 1998;84:852-8.

30. Davies D. Understanding biofilm resistance to antibacterial agents. Nat Rev Drug Discov. 2003;2(2):114-22.

31. Davies DG, Parsek MR, Pearson JP, Iglewski BH, Costerton JW, Greenberg EP. The involvement of cell-to-cell signals in the development of a bacterial biofilm. Science. 1998:280:295-8.

32. de Beer D, Stoodley P, Roe F, Lewandowski Z. Effects of biofilm structure on oxygen distribution and mass transport. Biotechnol Bioeng. 1994:43:1131-8.

33. de la Fuente-Nú̃nez C, Reffuveille F, Fernandez L, REW H. Bacterial biofilm development as a multicellular adaptation: antibiotic resistance and new therapeutic strategies. Curr Opi Microbiol. 2013;16:580e589.

34. Donlan RM. Biofilms and device-associated infections. Emerg Infect Dis. 2001;7:277-81

35. Esteban J, Martín-de-Hijas NS, Kinnari TJ, Ayala G, Fernández-Roblas R, Gadea I. Biofilm development by potentially pathogenic non-pigmented rapidly growing mycobacteria. BMC Microbiol. 2008;8:184.

36. Esteban J, Martín-de-Hijas NZ, García-Almeida D, Bodas-Sánchez A, Gadea I, Fernandez-Roblas R. Prevalence of erm methylase genes in clinical isolates of non-pigmented, rapidly growing mycobacteria. Clin Microbiol Infect. 2009:15:919-23.

37. Falkinham JO III. Nontuberculous mycobacteria in the environment. Clin Chest Med. 2002;23:529-51.

38. Falkinham JOIII. Surrounded by mycobacteria: nontuberculous mycobacteria in the human environment. J Appl Microbiol. 2009;107:356-67.

39. Flemming HC, Neu TR, Wozniak DJ. The EPS matrix: the "house of biofilm cells". J Bacteriol. 2007;189(22):7945-7.

40. Flemming HC, Wingender J, Szewzyk U, Steinberg P, Rice SA, Kjelleberg S. Biofilms: an emergent form of bacterial life. Nat Rev Microbiol. 2016;14(9): 563-75.

41. Fux CA, Costerton JW, Stewart PS, Stoodley P. Survival strategies of infectious biofilms. Trends Microbiol. 2005:13:34-40.

42. Gordon CA, Hodges NA, Marriott C. Antibiotic interaction and diffusion through alginate and exopolysaccharide of cystic fibrosisderived Pseudomonas aeruginosa. J Antimicrob Chemother. 1988;22:667-74.

43. Goto T, Nakame Y, Nishida M, Ohi Y. In vitro bactericidal activities of betalactamases, amikacin, and fluoroquinolones against Pseudomonas aeruginosa biofilm in artificial urine. Urology. 1999:53:1058-62.

44. Greendyke R, Byrd TF. Differential antibiotic susceptibility of Mycobacterium abscessus variants in biofilms and macrophages compared to that of planktonic bacteria. Antimicrob Agents Chemother. 2008;52:2019-26.

45. Ha KY, Chung YG, Ryoo SJ. Adherence and biofilm formation of Staphylococcus epidermidis andMycobacteriumtuberculosis on various spinal implants. Spine. 2005;30:38-43.

46. Halloum I, Carrere-Kremer S, Blaise M, Viljoen A, Bernut A, Le Moigne V, et al. Deletion of a dehydratase important for intracellular growth and cording renders roughMycobacterium abscessus avirulent. Proc Natl Acad Sci U S A. 2016;113:E4228-37. 
47. Helaine S, Kugelberg E. Bacterial persisters: formation, eradication, and experimental systems. Trends Microbiol. 2014;22:417-24.

48. Hernández-Sierra JF, Ruiz F, Cruz Pena DC. The antimicrobial sensitivity of Streptococcus mutans to nanoparticles of silver, zinc oxide, and gold. Nanomedicine. 2008a;4:237-40.

49. Hernández-Sierra JF, Ruiz F, Pena DC, Martínez-Gutiérrez F, Martínez AE, Guillén Ade J, Tapia-Pérez H, Castañón GM. The antimicrobial sensitivity of Streptococcus mutans to nanoparticles of silver, zinc oxide, and gold. Nanomed. 2008b;4:237-40.

50. Hochbaum Al, Kolodkin-Gal I, Foulston L, Kolter R, Aizenberg J, Losick R. Inhibitory effects of D-amino acids on Staphylococcus aureus biofilm development. J Bacteriol. 2011;193:5616-22.

51. Hoffmann N, Lee B, Hentzer M, Rasmussen TB, Song Z, Johansen HK, Givskov M, Høiby N. Azithromycin blocks quorum sensing and alginate polymer formation and increases the sensitivity to serum and stationary-growth-phase killing of Pseudomonas aeruginosa and attenuates chronic P. aeruginosa lung infection in Cftr2/2 mice. Antimicrob Agents Chemother. 2007;51:3677-87.

52. Hoiby N, Ciofu O, Johansen HK, Song ZJ, Moser C, Jensen P $\varnothing$, Molin S, Givskov M, Tolker-Nielsen T, Bjarnsholt T. The clinical impact of bacterial biofilms. Int J Oral Sci. 2011;3:55.

53. Huse HK, Kwon T, Zlosnik JE, Speert DP, Marcotte EM, Whiteley M. Pseudomonas aeruginosa enhances production of a non-alginate exopolysaccharide during long-term colonization of the cystic fibrosis lung. PLoS One. 2013;8:e82621.

54. lannitelli A, Grande R, Di Stefano A, Di Giulio M, Sozio P, Bessa LJ, Laserra S, Paolini C, Protasi F, Cellini L. Potential antibacterial activity of carvacrolloaded poly (DL-lactide-Co-glycolide) (PLGA) nanoparticles against microbial biofilm. Int J Mol Sci. 2011;12(8):5039-51.

55. Islam MS, Richards JP, Ojha AK. Targeting drug tolerance in mycobacteria: a perspective from mycobacterial biofilms. Expert Rev Anti-Infect Ther. 2012; 10:1055-66.

56. Jackson DW, Suzuki K, Oakford L, Simecka JW, Hart ME, Romeo T. Biofilm formation and dispersal under the influence of the global regulator CsrA of Escherichia coli. J Bacteriol. 2002;184:290-301.

57. Kalpana BJ, Aarthy S, Pandian SK. Antibiofilm activity of a-amylase from Bacillus subtilis S8-18 against biofilm forming human bacterial pathogens. Appl Biochem Biotechnol. 2012;167(6):1778-94.

58. Kaur G, Balamurugan P, Vasudevan S, Jadav S, Princy SA. Antimicrobial and Antibiofilm potential of acyclic amines and diamines against multi-drug resistant Staphylococcus aureus. Front Microbiol. 2017;8:1767.

59. Kennedy BS, Bedard B, Younge M, Tuttle D, Ammerman E, Ricci J, et al. Outbreak of Mycobacterium chelonae infection associated with tattoo ink. N Engl J Med. 2012;367:1020-4.

60. Keren I, Minami S, Rubin E, Lewis K. Characterization and transcriptome analysis of Mycobacterium tuberculosis persisters. mBio. 2011;2:e0100-11.

61. Khan W, et al. Aminoglycoside resistance of Pseudomonas aeruginosa biofilms modulated by extracellular polysaccharide. Int Microbiol. 2010;13:207-12.

62. Kohler P, Kuster SP, Bloemberg G, Schulthess B, Frank M, Tanner FC, et al. Healthcare-associated prosthetic heart valve, aortic vascular graft, and disseminated Mycobacterium chimaera infections subsequent to open heart surgery. Eur Heart J. 2015;36:2745-53.

63. Kolodkin-Gal I, Cao S, Chai L, Bo"ttcher T, Kolter R, Clardy J, Losick R. A selfproduced trigger for biofilm disassembly that targets exopolysaccharide. Cell. 2012;149:684-92.

64. Kolodkin-Gal I, Romero D, Cao S, Clardy J, Kolter R, Losick R. D-amino acids trigger biofilm disassembly. Science. 2010;328(5978):627-9.

65. Kragh KN, Hutchison JB, Melaugh G, Rodesney C, Roberts AEL, Irie Y, Jensen $P \varnothing$, Diggle SP, Allen RJ, Gordon V, Bjarnsholt T. Role of multicellular aggregates in biofilm formation. mBio. 2016;7(2):e00237-16.

66. Król JE, et al. Invasion of E. coli biofilms by antibiotic resistance plasmids. Plasmid. 2013;70:110-9.

67. Kulka K, Hatfull G, Ojha AK. Growth of Mycobacterium tuberculosis biofilms. J Vis Exp. 2012;15:e3820.

68. Kulshrestha S, Khan S, Hasan S, Khan ME, Misba L, Khan AU. Calcium fluoride nanoparticles induced suppression of Streptococcus mutans biofilm: an in vitro and in vivo approach. Appl Microbiol Biotechnol. 2016;100:1901-14.

69. Kulshrestha S, Khan S, Meena R, Khan AU. A graphene/zinc oxide nanocomposite film protects dental implant surfaces against cariogenic Streptococcus mutans. Biofouling. 2014;30:1281-94.

70. Kumar B, Sharma D, Sharma P, Katoch VM, Venkatesan K, Bisht D. Proteomic analysis of Mycobacterium tuberculosis isolates resistant to kanamycin and amikacin. J Proteome. 2013;94:68-77.
71. Kumon H, Tomochika K, Matunaga T, Ogawa M, Ohmori H. A sandwich cup method for the penetration assay of antimicrobial agents through Pseudomonas exopolysaccharides. Microbiol Immunol. 1994;38:615-9.

72. Lata M, Sharma D, Deo N, Tiwari PK, Bisht D, Venkatesan K. Proteomic analysis of ofloxacin-mono resistant Mycobacterium tuberculosis isolates. J Proteome. 2015;127:114-21.

73. Li L, Mendis N, Trigui H, Oliver JD, Faucher SP. The importance of the viablebut nonculturable state in human bacterial pathogens. Front Microbiol. 2014;5:258.

74. Lonn-Stensrud J, Landin MA, Benneche T, Petersen FC, Scheie AA. Furanones, potential agents for preventing Staphylococcus epidermidis biofilm infections. J Antimicrob Chemother. 2009;63:309-16.

75. Madsen JS, Burmølle M, Hansen HL, Sørensen SJ. The interconnection between biofilms formation and horizontal gene transfer. FEMS Immunol Med Microbiol. 2012;65:183-95.

76. Magnet $\mathrm{S}$, Courvalin P, Lambert T. Resistance modulation cell division type efflux pump involved in aminoglycoside resistance in Acinetobacter baumannii BM4454. Antimicrob Agents Chemother. 2001;45:3375-80.

77. Magnet S, Smith TA, Zheng R, Nordmann P, Blanchard JS. Aminoglycosides resistance resulting from tight drug binding to an altered aminoglycosides acetyl transferase. Antomicrob Agents Chemother. 2003;47:1577-83.

78. Mah T-F, O'Toole GA. Mechanisms of biofilm resistance to antimicrobial agents. Trends Microbiol. 2001;9:34-9.

79. Mah T-F. Biofilm-specific antibiotic resistance. Future Microbiol. 2012;7: 1061-72.

80. Maisonneuve E, Gerdes K. Molecular mechanisms underlying bacterial persisters. Cell. 2014;157:539-48.

81. Maya-Hoyos M, Leguizamón J, Mariño-Ramírez L, Soto CY. Sliding motility, biofilm formation, and glycopeptidolipid production in Mycobacterium colombiense strains. Biomed Res Int. 2015;2015:419549.

82. McCarty SM, Cochrane CA, Clegg PD, Percival SL. The role of endogenous and exogenous enzymes in chronic wounds: a focus on the implications of aberrant levels of both host and bacterial proteases in wound healing. Wound Repair Regen. 2012;20:125-36.

83. Menozzi FD, Rouse JH, Alavi M, Laude-Sharp M, Muller J, Bischoff R, et al. Identification of a heparin-binding hemagglutinin present in mycobacteria. J Exp Med. 1996;184:993-1001.

84. Metwalli KH, Khan SA, Krom BP, Jabra-Rizk MA. Streptococcus mutans, Candida albicans, and the human mouth: a sticky situation. PLoS Pathog. 2013:9:e1003616.

85. Minardi D, Cirioni O, Ghiselli R, Silvestri C, Mocchegiani F, Gabrielli E, d'Anzeo G, Conti A, Orlando F, Rimini M, Brescini L. Efficacy of tigecycline and rifampin alone and in combination against enterococcus faecalis biofilm infection in a rat model of ureteral stent. J Surg Res. 2012;176:1-6.

86. Misba L, Khan AU. Enhanced photodynamic therapy using light fractionation against S. mutans biofilm: type I and type II mechanism. Future Microbiol. 2018;13:437-54. https://doi.org/10.2217/fmb-2017-0207.

87. Misba L, Kulshrestha S, Khan AU. Antibiofilm action of a toluidine blue Osilver nanoparticle conjugate on Streptococcus mutans: a mechanism of type I photodynamic therapy. Biofouling. 2016;32(3):313-28.

88. Misba L, Zaidi S, Khan AU. A comparison of antibacterial and antibiofilm efficacy of phenothiazinium dyes between gram positive and gram negative bacterial biofilm. Photodiagn Photodyn Ther. 2017;18:24-33.

89. Monzón M, Oteiza C, Leiva J, Lamata M, Amorena B. Biofilm testing of Staphylococcus epidermidis clinical isolates: low performance of vancomycin in relation to other antibiotics. Diagn Microbiol Infect Dis. 2002; 44:319-24.

90. Muñoz-Egea MC, Esteban M, Esteban J. "Inhibition of Mycobacterium abscessus biofilms by Methylobacterium sp," in 29th ECCMI (Amsterdam); 2016

91. Muñoz-Egea MC, García-Pedrazuela M, Mahillo I, Esteban J. Effect of ciprofloxacin in the ultrastructure and development of biofilms formed by rapidly growing mycobacteria. BMC Microbiol. 2015;15:18.

92. Muñoz-Egea MC, Garcia-Pedrazuela M, Mahillo-Fernandez I, Esteban J. Effect of antibiotics and antibiofilm agents in the ultrastructure and development of biofilms developed by nonpigmented rapidly growing mycobacteria. Microb Drug Resist. 2016;22:1-6.

93. Muñoz-Egea MC, García-Pedrazuela M, Mahillo I, García MJ, Esteban J. Autofluorescence as a tool for structural analysis of biofilms formed by nonpigmented rapidly growing mycobacteria. Appl Environ Microbiol. 2013; 79:1065-7. 
94. Nayak N. Mycobacterium tuberculosis biofilm-a new perspective. Indian J Tuberc. 2015;62:4-6.

95. Nichols WW, Dorrington SM, Slack MPE, Walmsley HL. Inhibition of tobramycin diffusion by binding to alginate. Antimicrob Agents Chemother. 1988;32:518-23

96. Nikaido $\mathrm{H}$. Molecular basis of bacterial outer membrane permeability revisited. Microbiol Mol Biol Rev. 2003;67:593-656.

97. Nithya C, Devi MG, Karutha Pandian S. A novel compound from the marine bacterium Bacillus pumilus S6-15 inhibits biofilm formation in gram-positive and gram-negative species. Biofouling. 2011;27:519-28.

98. OToole G, Kaplan HB, Kolter R. Biofilm formation as microbial development. Annu Rev Microbiol. 2000;54:49-79.

99. O'Toole GA, Kolter R. Flagellar and twitching motility are necessary for Pseudomonas aeruginosa biofilm development. Mol Microbiol. 1998;30: 295-304.

100. Ojha AK, Baughn AD, Sambandan D, Hsu T, Trivelli X, Guerardel Y, et al. Growth of Mycobacterium tuberculosis biofilms containing free mycolic acids and harbouring drug-tolerant bacteria. Mol Microbiol. 2008;69:164-74.

101. Ojha AK, Jacobs WR Jr, Hatfull GF. Genetic dissection of mycobacterial biofilms. Methods Mol Biol. 2015;1285:215-26.

102. Ojha A, Anand M, Bhatt A, Kremer L, Jacobs WR Jr, Hatfull GF. GroEL1: a dedicated chaperone involved in mycolic acid biosynthesis during biofilm formation in mycobacteria. Cell. 2005:123:861-73.

103. Ortiz-Perez A, Martin-de-Hijas N, Alonso-Rodriguez N, Molina-Manso D, Fernandez-Roblas R, Esteban J. Importance of antibiotic penetration in the antimicrobial resistance of biofilm formed by non-pigmented rapidly growing mycobacteria against amikacin, ciprofloxacin and clarithromycin. Enferm Infecc Microbiol Clin. 2011;29:79-84.

104. Otto M. Staphylococcal infections: mechanisms of biofilm maturation and detachment as critical determinants of pathogenicity. Annu Rev Med. 2013; 64:175-88.

105. Oubekka SD, Briandet R, Fontaine-Aupart MP, Steenkeste K. Correlative timeresolved fluorescence microscopy to assess antibiotic diffusion reaction in biofilms. Antimicrob Agents Chemother. 2012;56:3349-58.

106. Pelgrift RY, Friedman AJ. Nanotechnology as a therapeutic tool to combat microbial resistance. Adv Drug Deliv Rev. 2013;65:1803-15.

107. Plaetzer K, Krammer B, Berlanda J, Berr F, Kiesslich T. Photophysics and photochemistry of photodynamic therapy: fundamental aspects. Lasers Med Sci. 2009;24:259-68.

108. Prigent-Combaret C, Vidal O, Dorel C, Lejeune P. Abiotic surface sensing and biofilm-dependent regulation of gene expression in Escherichia coli. J Bacteriol. 1999;181:5993-6002.

109. Qu Y, Daley AJ, Istivan TS, Rouch DA, Deighton MA. Densely adherent growth mode, rather than extracellular polymer substance matrix build-up ability, contributes to high resistance of Staphylococcus epidermidis biofilms to antibiotics. J Antimicrob Chemother. 2010;65:1405-11.

110. Qvist T, Pressler T, Høiby N, Katzenstein TL. Shifting paradigms of nontuberculous mycobacteria in cystic fibrosis. Respir Res. 2014;15:1.

111. Recht J, Kolter R. Glycopeptidolipid acetylation affects sliding motility and biofilm formation in Mycobacterium smegmatis. J Bacteriol. 2001; 183:5718-24.

112. Recht J, Martinez A, Torello S, Kolter R. Genetic analysis of sliding motility in Mycobacterium smegmatis. J Bacteriol. 2000;182:4348-51.

113. Romero Diaz R, Picciafuoco S, Paraje MG, Angel Villegas N, Arce Miranda E, Albesa I, Cremonezzi D, Commisso R, Paglini-Oliva P. Relevance of biofilms in pediatric tonsillar disease. Eur J Clin Microbiol Infect Dis. 2011;30(12): 1503-9.

114. Savage VJ, Chopra I, O’Neill AJ. Staphylococcus aureus biofilms promote horizontal transfer of antibiotic resistance. Antimicrob Agents Chemother. 2013:57:1968-70

115. Schulze-Robbecke R. Immun Infekt. 1993). [Mycobacteria in the environment:21:126-31.

116. Schulze-Röbbecke $R$, Janning B, Fischeder R. Occurrence of mycobacteria in biofilm samples. Tuber Lung Dis. 1992;73:141-4.

117. Sharma D, Kumar B, Lata M, Joshi B, Venkatesan K, Shukla S, et al. Comparative proteomic analysis of aminoglycosides resistant and susceptible Mycobacterium tuberculosis clinical isolates for exploring potential drug targets. PLoS One. 2015;10(10):e0139414.

118. Sharma D, Lata M, Singh R, Deo N, Venkatesan K, Bisht D. Cytosolic proteome profiling of aminoglycosides resistant Mycobacterium tuberculosis clinical isolates using MALDI-TOF/MS. Front Microbiol. 2016;7:1816.
119. Shigeta M, Tanaka G, Komatsuzawa H, Sugai M, Suginaka H, Usui T. Permeation of antimicrobial agents through Pseudomonas aeruginosa biofilms: a simple method. Chemotherapy. 1997:43:340-5

120. Singh PK, Schaefer AL, Parsek MR, Moninger TO, Welsh MJ, Greenberg EP. Quorum-sensing signals indicate that cystic fibrosis lungs are infected with bacterial biofilms. Nature. 2000:407(6805):762-4.

121. Solano C, Echeverz M, Lasa I. Biofilm dispersion and quorum sensing. Curr Opin Microbiol. 2014;18:96-104.

122. Song Z, Kong KF, Wu H, Maricic N, Ramalingam B, Priestap H, Schneper L, Quirke JME, Høiby N, Mathee K. Panax ginseng has anti-infective activity against opportunistic pathogen Pseudomonas aeruginosa by inhibiting quorum sensing, a bacterial communication process critical for establishing infection. Phytomedicine. 2010:17:1040-6.

123. Spinner RJ, Sexton DJ, Goldner RD, Levin LS. Periprosthetic infections due to Mycobacterium tuberculosis in patients with no prior history of tuberculosis J Arthroplast. 1996;11:217-22.

124. Stewart PS. A review of experimental measurements of effective diffusive permeabilities and effective diffusion coefficients in biofilms. Biotechnol Bioeng. 1998:59:261-72.

125. Stewart PS. Theoretical aspects of antibiotic diffusion into microbial biofilms Antimicrob Agents Chemother. 1996;40:2517-22

126. Stewart PS, William Costerton J. Antibiotic resistance of bacteria in biofilms. Lancet. 2001;358:135-8.

127. Sugimoto $S$, et al. Imaging of bacterial multicellular behaviour in biofilms in liquid by atmospheric scanning electron microscopy. Sci Rep. 2016;6:25889.

128. Sun F, Qu F, Ling Y, Mao P, Xia P, Chen H, Zhou D. Biofilm-associated infections: antibiotic resistance and novel therapeutic strategies. Future Microbiol. 2013;8:877-86.

129. Tack KJ, Sabath LD. Increased minimum inhibitory concentrations with anaerobiasis for tobramycin, gentamicin, and amikacin, compared to latamoxef, piperacillin, chloramphenicol, and clindamycin. Chemotherapy. 1985:31:204-10.

130. Takei S, Hotomi M, Yamanaka N. Minimal biofilm eradication concentration of antimicrobial agents against nontypeable Haemophilus influenzae isolated from middle ear fluids of intractable acute otitis media. J Infect Chemother. 2013:19:504-9.

131. Tetz GV, Artemenko NK, Tetz W. Effect of DNase and antibiotics on biofilm characteristics. Antimicrob Agents Chemother. 2009:53:1204-9.

132. Tuomanen E, Cozens R, Tosch W, Zak O, Tomasz A. The rate of killing of Escherichia coli by $\beta$-lactam antibiotics is strictly proportional to the rate of bacterial growth. J Gen Microbiol. 1986;132:1297-304.

133. van Ingen J, Boeree MJ, Dekhuijzen PN, van Soolingen D. Environmental sources of rapid growing nontuberculous mycobacteria causing disease in humans. Clin Microbiol Infect. 2009;15:888-93.

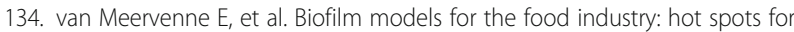
plasmid transfer? Pathog Dis. 2014;70:332-8.

135. Vijayaraghavan R, Chandrashekhar R, Sujatha Y, Belagavi CS. Hospital outbreak of atypical mycobacterial infection of port sites after laparoscopic surgery. J Hosp Infect. 2006:64:344-7.

136. Walker J, Moore G, Collins S, Parks S, Garvey MI, Lamagni T, et al. Microbiological problems and biofilms associated with Mycobacterium chimaera in heater-cooler units used for cardiopulmonary bypass. J. Hosp. Infect. 2017:96:209-20.

137. Walsh C. Molecular mechanisms that confer antibacterial drug resistance. Nature. 2000:406:775-81.

138. Welch KT, Virga KG, Whittemore NA, Ozen C, Wright E, Brown CL, et al. Discovery of non-carbohydrate inhibitors of aminoglycoside-modifying enzymes. Bioorg Med Chem. 2005;13:6252-363.

139. Werner E, Roe F, Bugnicourt A, Franklin MJ, Heydorn A, Molin S, et al. Stratified growth in Pseudomonas aeruginosa biofilms. Appl Environ Microbiol. 2004;70:6188-96.

140. Whitchurch CB, Tolker-Nielsen T, Ragas PC, Mattick JS. Extracellular DNA required for bacterial biofilm formation. Science. 2002;295:1487.

141. Whiteley M, Bangera MG, Bumgarner RE, Parsek MR, Teitzel GM, Lory S, Greenberg EP. Gene expression in Pseudomonas aeruginosa biofilms. Nature. 2001:413:860-4

142. Wiley L, Bridge DR, Wiley LA, Odom JV, Elliott T, Olson JC. Bacterial biofilm diversity in contact lens-related disease: emerging role of Achromobacter, Stenotrophomonas, and Delftia biofilm diversity in contact lens-related disease. Invest Ophthalmol Vis Sci. 2012;53:3896-905. 
143. Wilkins M, Hall-Stoodley L, Allan RN, Faust SN. New approaches to the treatment of biofilm-related infections. J Infect. 2014;69:S47-52.

144. Williams I, Venables WA, Lloyd D, Paul F, Critchley I. The effects of adherence to silicone surfaces on antibiotic susceptibility in Staphylococcus aureus. Microbiology. 1997;143:2407-13.

145. Williams MM, Yakrus MA, Arduino MJ, Cooksey RC, Crane CB, Banerjee SN, et al. Structural analysis of biofilm formation by rapidly and slowly growing nontuberculous mycobacteria. Appl EnvironMicrobiol. 2009;75:2091-8.

146. Wingender J, Strathmann M, Rode A, Leis A, Flemming HC. Isolation and biochemical characterization of extracellular polymeric substances from Pseudomonas aeruginosa. Methods Enzymol. 2001;336:302-14.

147. Xu KD, McFeters GA, Stewart PS. Biofilm resistance to antimicrobial agents. Microbiology. 2000;146:547-9.

148. Zaidi S, Misba L, Khan AU. Nano-therapeutics: a revolution in infection control in post antibiotic era. Nanomedicine. 2017:13(7):2281-301.

149. Zambrano MM, Kolter R. Mycobacterial biofilms: a greasy way to hold it together. Cell. 2005;123:762-4.

150. Zamora N, Esteban J, Kinnari TJ, Celdran A, Granizo JJ, Zafra C. In-vitro evaluation of the adhesion to polypropylene sutures of nonpigmented, rapidly growing mycobacteria. Clin Microbiol Infect. 2007;13:902-7.

151. Zhang TC, Bishop PL. Evaluation of substrate and pH effects in a nitrifying biofilm. Wat Environ Res. 1996:68:1107-15

152. Zlosnik JE, Costa PS, Brant R, Mori PY, Hird TJ, Fraenkel MC, Wilcox PG, Davidson AGF, Speert DP. Mucoid and nonmucoid Burkholderia cepacia complex bacteria in cystic fibrosis infections. Am J Respir Crit Care Med. 2011;183:67-72.

153. Zuberi A, Ahmad N, Khan AU. CRISPRi induced suppression of fimbriae gene (fimH) of a Uropathogenic Escherichia coli: An approach to inhibit microbial biofilms. Front Immunol. 2017a;8:1552.

154. Zuberi A, Misba L, Khan AU. CRISPR interference (CRISPRi) inhibition of luxS gene expression in E. coli: an approach to inhibit biofilm. Front Cell Infect Microbiol. 2017b;7:214

Ready to submit your research? Choose BMC and benefit from:

- fast, convenient online submission

- thorough peer review by experienced researchers in your field

- rapid publication on acceptance

- support for research data, including large and complex data types

- gold Open Access which fosters wider collaboration and increased citations

- maximum visibility for your research: over $100 \mathrm{M}$ website views per year

At $\mathrm{BMC}$, research is always in progress.

Learn more biomedcentral.com/submissions 